\title{
SPELEOTHERAPY DEVELOPMENT IN ROMANIA ON THE WORLD CONTEXT AND PERSPECTIVES FOR USE OF SOME SALT MINES AND KARST CAVES FOR SPELEOTHERAPEUTIC AND BALNEOCLIMATIC TOURISM PURPOSES
}

Iuri SIMIONCA ${ }^{1,2}$

\begin{abstract}
National Institute of Rehabilitation, Physical Medicine and Balneoclimatology, Bucharest, Romania ${ }^{1}$; The Permanent Commission on Speleotherapy (PCS) / Commission permanente de spéléothérapie (CPS) - UIS ${ }^{2}$ Corresponding author: simionca_iuri@yahoo.com
\end{abstract}

Key words: speleotherapy, speleotherapy status, speleotherapy development

Speleotherapy (ST) is a relatively new method of complementary medicine, although, as is well known ancient tribes appreciated isolation in underwater caves, salt or karst caves, or possessing various ores and was officially recognized in the years 1950-1960 in Germany (K.Spannagel, 1961) and Poland (M. Skulimowski, 1965). Professor Mieczyslaw Skulimowski has granted of speleotherapy in "Wieliczka" Salt Mine, the name of subterraneotherapy, soon to be also called the Skulimowski method. Number of speleotherapeutic centers and speleotherapy symposiums has increased considerably (H.Trimmel, 1994). Speleotherapy in the underground now is an effective therapeutic method for the treatment of obstructive respiratory tract diseases, especially of patients with bronchial asthma (BA), the upward and effective practice in Central and Eastern Europe, but also in the West: Austria, Czech Republic, Germany, Poland, Russia, Slovakia, Ukraine, Belarus, Hungary etc.

In the World, known about 60 underground salt and other mines, carst caves used for ST or are under experimental study to evaluate the possibility to be used for speleotherapy, including: Germany, Hungary, Czech Republic, Slovakia, Austria, Slovenia, Ukraine, Romania and other countries. In salt mines with 9-24 ${ }^{\circ} \mathrm{C}$ temperature operating 15 speleotherapy centers, 34 in karst caves with $9-18{ }^{\circ} \mathrm{C}$, and 4 centers in thermal caves with temperatures higher than 24 C (Iu. Simionca et al., 2005). In the last twenty years ST occupies an important place in salt mines mines and carst caves with different parameters: Wieliczka, Poland; Solotvino / Slatina, Ukraine; Bad Bleiberg, Austria; Klutert Hohl, Germany; Zlate Hory and Cisarska Cave, Czech Republic; Bystrianska Jaskyna, Slovakia; Tapolca Seehohle, Hungary; "Unirea" Salt Mine - Slănic Prahova, Romania and will occupy a significant place the Turda Salt Mine, Cacica, Tg. Ocna, and Praid salt mines from Romania (Iu.Simionca et al., 2006, 2009).

Is of scientific and practical interest formation in world of new directions in the treatment of the most common and severe allergic diseases - asthma, namely the use of underground environmental factors in order to reduce human outcome of the action of environmental allergy. In this context, the use of salt mines and caves as natural therapeutic factors - also known as speleotherapy, is a special scientific interest, a perspective direction in the areas of health and environment.

Today speleotherapy is known as the therapy of patients with various diseases in the underground salt mines and caves possessing natural therapeutic factors (Iu.Simionca et al., 1998, 2005, 2006, 2009).

Analysis of the speleotherapy domain status allowed to establish that use saline or cave underground natural environmental factors which own curative properties for prevention, treatment and rehabilitation of patients with certain diseases, often 
chronic and severe (asthma, post burn complications) represents a potential solution to optimize health services and increase quality of life.

In order to evaluate speleotherapy centers and the development of speleotherapy in Central and Eastern Europe, in the years 2010 - 2012 by board members of international Permanent Commission on Speleothjerapy (PCS) were vizited:

- Moravia Children's Specialized Health Care Center, Children's Sanatorium with Speleotherapy, Ostrov u Macochy, Czech Republic;

- Sanatorium Edel, Children's Sanatorium with Speleotherapy, Zlate Hory , Czech Republic;

- Regional Allergic Hospital with underground section of speleotherapy in Salt Mine N8, Solotvino, Ukraine;

- Republikan

(Ukrainian)

Allergologic Hospital, with underground section of speleotherapy in Salt Mine N8, Solotvino, Ukraine;

- Scientific-Medical Centre and Clinic "Rehabilitation" (Halotherapy Centre) Health Ministry of Ukraine, Uzhgorod, Ukraine;

- Speleotherapy Center in Bistra cave near Banska Bystrica, Slovakia;

- Turda Salt Mine Complex with Salt mines Ghizela, Rudolf, Terezia and underground sections destinated for speleotherapy, Cluj county, Romania;

- Praid salt Mine with underground sections for agrement and tourism, Harghita county, Romania;

- Respublikanskaia bolnitsa speleolecheniya in Solegorsk Salt mine Complex with two underground speleotherapeutic sections, Solegorsk, Belarus Republik.

The results were presented at the XIVth International Symposium of Speleotherapy-UIS, 2012, Turda, Romania (Jaroslav Chonka, Iuri Simionca, Pavel Slavik, 2012). To mention the following results:
Significant experience in treating patients, especially children, is obtained in karst caves of Czech Republic and Slovakia. The most significant center in the Czech Republic is the resort "Golden Mountain", where 2,000 patients are treated annually. The health resort is comfortable for accommodation and treatment of patients. It has a stable and favorable microclimate in the mine, where gold and other polymetals mined.

In recent years another important center in the Czech Republic - Children's Health Center - "Island in Macocha" loses its importance. It has all the possibilities of accommodation, treatment of children, but due to organizational problems this treatment facility is not working at full capacity, which causes considerable concern in the medical community. Another speleotherapy center is in Slovakia - Bistra cave near Banska Bystrica.

In Poland is the oldest in Europe speleotherapy center in salt mines Wieliczka.

Speleotherapy (subteranneotherapy) center in Wieliczka is the main medical center in Europe in terms of accommodation, the effectiveness of treatment and the number of treated patients. Wieliczka experience should transferred to another salt mine in Poland Bohnya, which also has room for development of speleotherapy.

Good development of speleotherapy is obtained in Belarus, where thanks to the government in Solihorsk, where a new underground department at the potash mines has been built recently and a new building of Republican speleotherapeutic clinic was built which enables to increase the number of treated patients in two times.

Significant losses in 2009-2010 in speleotherapy was flooded salt mines in Solotvino (Ukraine), where there was the world's largest underground mine department number 9 where 4-5 thousand patients were treated annually. 
Although at the availability of funds and desire the work of Solotvino salt mines and speleotherapy can be resumed.

However, the most promising development of speleotherapy in salt mines is Romania, which is located at 3 centers, which can perform speleotherapy in classic form. The results of the bioclimatic studies, the pollution evaluation, studies on the microorganisms in the salt mines from Cacica, Slănic Prahova, Praid, Tg. Ocna and Turda in the years 1970-2004 revealed that some of these mines could be used for medical purposes and tourism. Were proposed the solutions for reduction of the anthropic pollution effect (Grant CNCSIS, 2004).

For the moment, in Romania the speleotherapy is used for asthma patients, chronic bronchitis and correction effect whose immunopathological changes - the new perspective for speleotherapy, in Slănic Prahova „Unirea” Salt Mine - the subject of a multidisciplinary medical and environmental study (VIASAN Project No. 441, Life and Health - 2004-2006).

Another realized RDI project (Nr.2550, FC:42120/2008-2011) is „Complex of medical-biological study of potential therapeutic factors related to salt mines and karst environments for effective use in health and balneo-turism; development and modelling solutions of these factors". A particular interest represents new location of Cacica Salt Mine and Ocna Dej Salt Mine.

One promising for medical use is Turda Salt Mine, adapted for tourists and for sick people (PHARE Project, finalized in 2009). Studies results (Proiects / Financing Contract 310/2010 and $600 / 2011$ - 2012) indicated the specific speleotherapeutic effect. Now in Romania, in the various national scientific research projects, coordinated by MSR II, Dr. Iuri Simionca, an intensive examination of these salt mines speleotherapeutic potential, inclusive the influence of underground microclimate on laboratory animals with induced pathology and on human patients with bronchial asthma, chronic bronchitis and other pathology, for organizing with Romanian Salt Company a system of speleotherapeutic centers in salt mines ("Unirea"- Slanic Prahova, Turda, Cacica, Dej, Praid, Tg.Ocna, Rm. Valcea salt mines).

The new directions is speleotherapy in carst caves which possess curative properties. Are of use interest in the speleotherapeutic purposes the Carst Cave Fundata - Rasnov, Brasov, where results of the first studies are promising (Iu. Simionca et al., 2012)
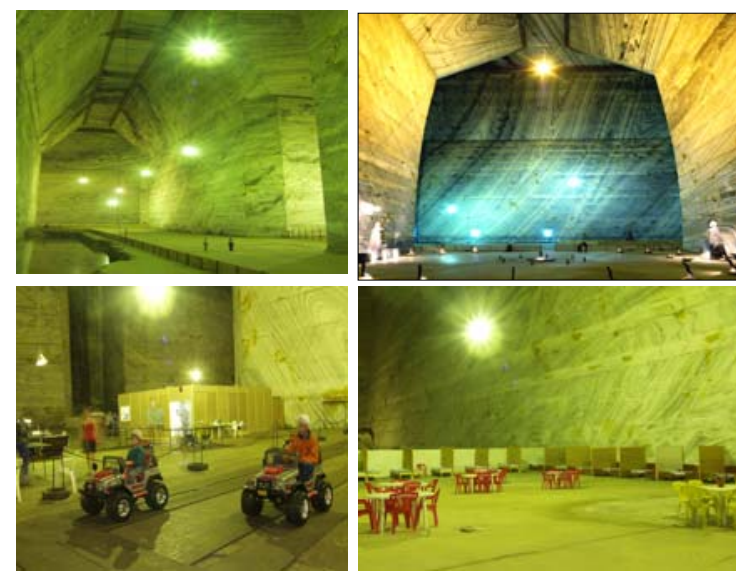

Figure 1. Foto 1 - 4. Recreational and treatment area in Salt Mina "Unirea», Slănic Prahova, Romania (Proiect No. 441 VIASAN Romania, 2004 - 2007)

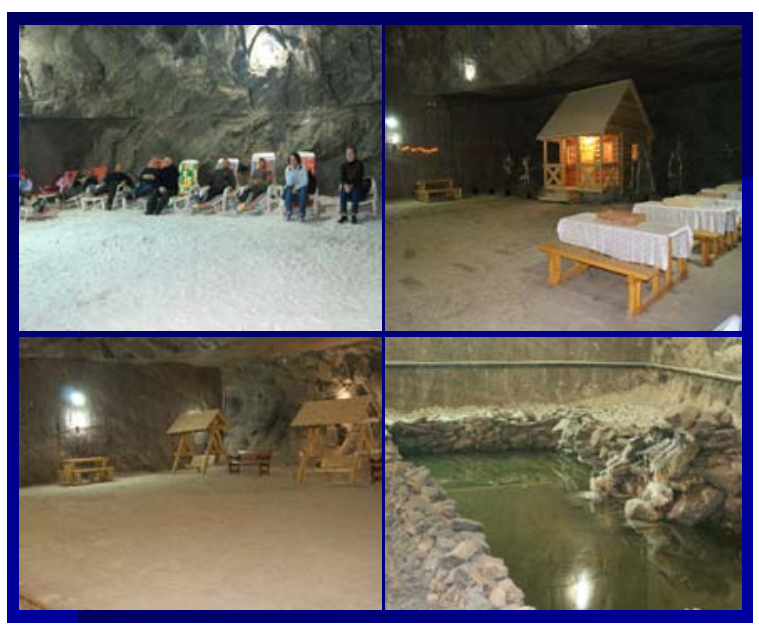

Figure 2. Photo 5-8. Photo by C. Zup. "Procedure of speleotherapy in „Underground experimental speleotherapeutic sections" in Gallery 1 designed for speleotherapy and recreation, Cacica salt Mine ("Old salt Mine"), Suceava 


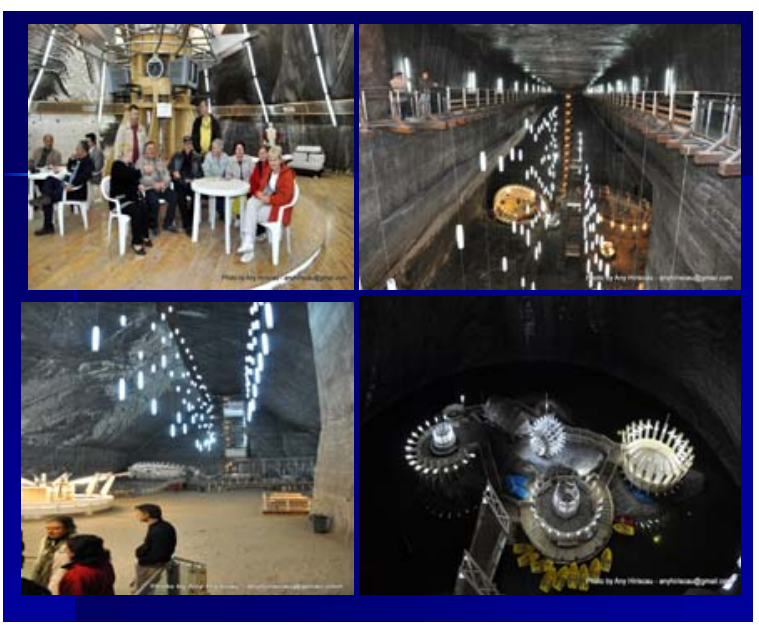

Figure 3. Photo 9-12. „Underground speleotherapeutic sections" and sections for recreation in salt mines Ghizela, Rudolf $a-b$ and Therezia - Salt Mine Complex Turda, Cluj County, Romania

In 2011, October $06-08$, in Turda city, Cluj county, Romania, was organized "The First Romanian Conference on Speleotherapy" (with international participation), dedicated to the project entitled Complex medico - biological study for innovative use of potential therapeutic salt mines and cave environmental factors in health resorts and balneoclimatic tourism; their modeling solutions" (National RDI-2 Plan, Project 42120/2008-2011, Project Manager - MSR II, Dr. Iuri Simionca) and for development of Speleotherapy in Romania (National Institute for Rehabilitation Physical Medicine and Balneoclimatology, from Bucharest). The conference was organized under the aegis of:

- Executive Unit for Financing Higher Education, the Research, Development and Innovation (UEFISCDI) under the authority of Ministry of Education, Research, Youth and Sports;

- The Permanent Commission on Spe leotherapy (PCS/CPS) -UIS;

- Academy of Medical Sciences of Romania, Bucharest.
At the conference was attended various experts in speleotherapy, pulmonology and alergology, salt mines activity and caves tourism, including 12 participants from Ukraine and Czech Republic - representatives of speleotherapy centers among which Former President PCS/CPS-UIS Dr., MUDr. Pavel Slavik and Vice President PCS/CPS-UIS Dr., M.D. Jarosla Chonka.

Conference summaries are published in the abstract book, printed in Publishing House "Casa cartii de stiinta", ClujNapoca - recognized by National Council of Scientific Research in Higher Education and with title and description CIP of National Library, Romania (Iu.Simionca et al., 2012)

In the last 12 years occurred various scientific meetings in the field, including: The XI International Symposium of Speleotherapy, Zlate Hory, EDEL - Czech Republic, 1999; The National Congress of Physical and Rehabilitation Medicine, Techirghiol, Romania, 2001, with section of speleotherapy and other National Congress of Physical and Rehabilitation Medicine, Romania, during 2001 - 2010 years; The 14 th International Congress of Speleology, UIS, Athens, Kalamos, 2005 with section of speleotherapy; International Symposium of allergologists - "30 years of Speleotherapy in Ukrainian Allergological Hospital" Solotvino - Ukraine, 2006; National Conference of Balneology with section of speleotherapy, Sovata, Romania, 2009 - 2012 (being promoted and sustained the results of multidisciplinary scientific and exploratory research from Romania in the field - studies, experiments and research projects. 


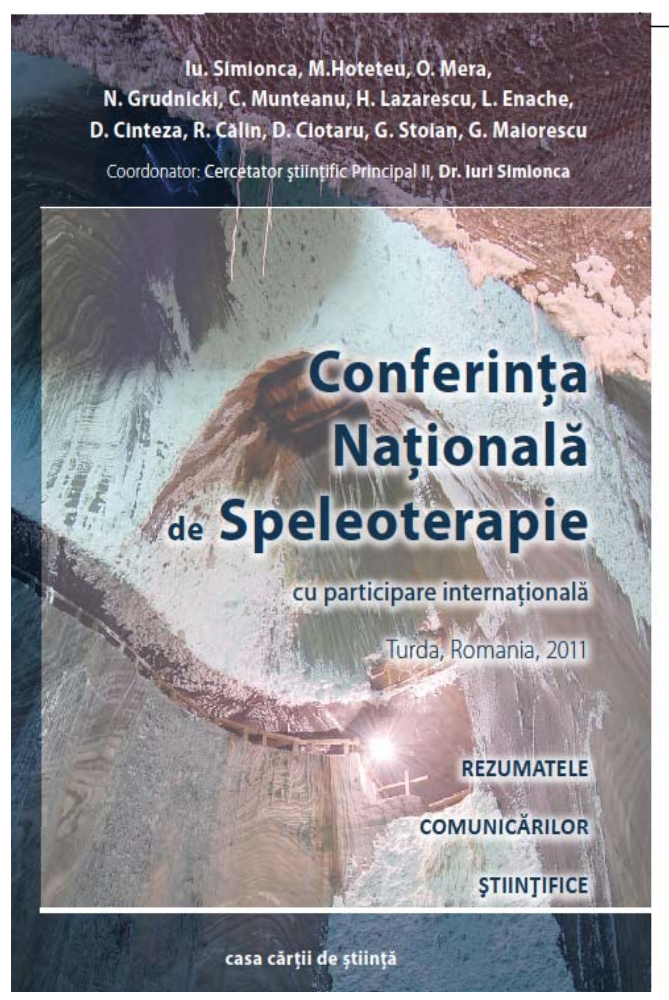

Since 1969 year were achieved 13 editions of "The International Symposium of Speleotherapy" and other editions of seminars and conferences in the field, organized of Permanent Commission of Speleotherapy - UIS in Austria, Germany, Czech Republic, Slovakia, Slovenia, Ukraine, Russia, Hungary, Italy and other countries, including ,The XIII th International Symposium on Speleotherapy, Czech Republic, Blansko, 2008".

The XIV International Symposium of Speleotherapy (XIV ISS-UIS), organized by the Permanent Commission on Speleotherapy (PCS) / Commission permanente de spéléothérapie (CPS) Department of Research / Département de la recherché scientifique - UIS, in the town of Turda, Cluj County, Transylvania, Romania, in 4 to 6 October 2012 (Decision of the Permanent Commission on Speleotherapy - UIS, Working Committee Meeting, 27 - 28 March 2012, Ostrov u Macochy, Brno, Czech Republic - Wieliczka, Krakow, Poland).

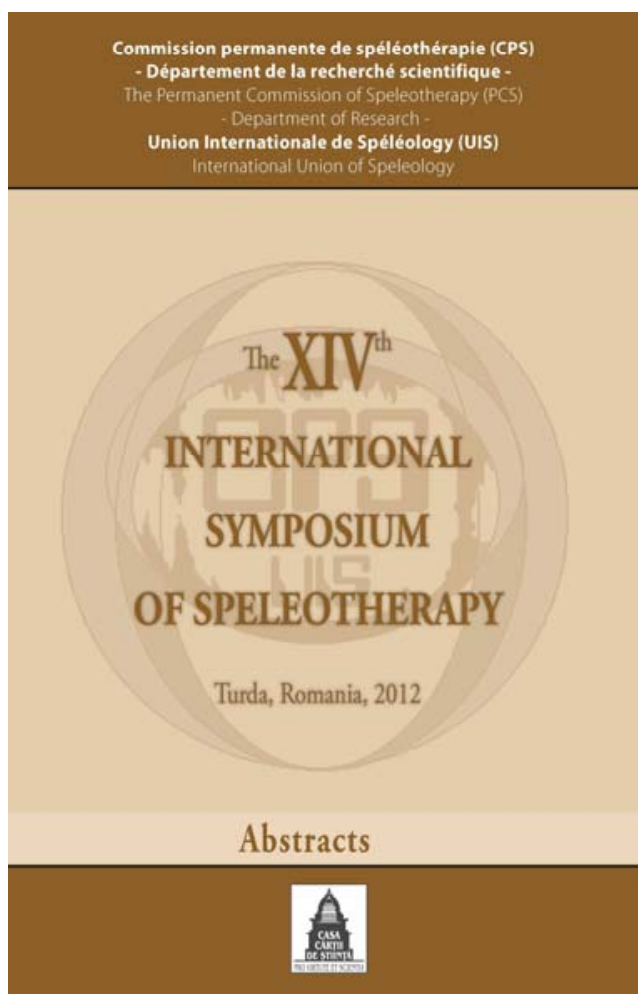

At the closing session of the XIV ${ }^{\text {th }}$ International Symposium on Speleotherapy, 2012 (Turda, Romania) noted that lectures and communications (including poster) had a high scientific level, bringing the current results of the latest research in speleo and halotherapy field (from studies of underground karst and salt mine environment, of engineering protection and biomedical experimental studies on laboratory animals and to clinical, cellular and molecular immunology, hematology, biochemistry, physiology and others) made in various countries, including Romania.

Were discussed problems and potential development priorities in the field.

The participants of the XIV th International Symposium on Speleotherapy of the PCS / CPS-UIS, they are representatives of the Academy of Scientists from Romania and the Academy of Medical Sciences of Romania, professors, associate professors and university lecturers from different countries, including Romania; directors of research institutes in the public and private 
sectors, researchers of different degrees, doctors in sciences (doctors, biologists, chemists, engineers, speleologists, geologists and other specialists) both from Romania and from other countries; representatives of some state institutions from Romania, business and industry from different countries and of Romania, discussed the current status of speleotherapy in caves and mines, as well as halotherapy - descending method of speleotherapy in salt mines.

The analysis of the current status in the field (Iu. Simionca et al., 2005, 2006, 2009, J.Chonka, Iu. Simionca, P. Slavik, 2012) showed the existence of a series of fundamental issues - potential development priorities in the field of speleotherapy in caves or mines and of halotherapy:

- the enhanced interest of a large category of persons in different countries (preponderant in Europe) for medical and touristic services in original and specific locations with therapeutic natural factors, such as those from some caves or salt mines and chambers with artificial underground salt mine environment or microclimate (halotherapy method descending from speleotherapy in salt mines);

- lack of technical and medical standards for use in medical / speleotherapeutic and of balneoclimatic tourism some caves and mines (mainly salt mines, and other mines) and for halotherapy - the surface rooms with salt mine underground artificial environment or underground salt mine microclimate;

- need for monitoring standards of geomechanical stability of the underground spaces in caves and mines which possesses speleotherapeutic factors and used for medical purposes. balneoclimatic tourism or speleo- and salt mine tourism;

- lack of monitoring standards for curative properties of some caves and mines (including salt mines), assessing their stability and therapeutic effectiveness, particularly after using for cave or salt mine tourism and medical balneoclimatic tourism or speleotherapy (after human impact);

- adequate measures for preserving / restoring the specific underground environmental factors;

- the necessity of approaching and launching at national level of researches on methodologies regarding speleotherapy, related to the presence and the quality of underground therapeutic factors and to the medical history of the patients (age, disease status, previous medication, especially the hormonal therapy).

These issues could build up a development program of speleotherapy and descending methods used in medical purposes, for balneoclimatic tourism, caves or salt minestourism over a period of several years, which would involve increasing the quality of human life.

\section{References:}

1. Chonka J., Simionca Iu., Slavik P. The development of speleotherapy in Eastern Europe (2012). INTERNATIONAL SYMPOSIUM OF SPELEOTHERAPY. International Symposium (14; 2012; Turda). The XIVth International Symposium of Speleotherapy : Abstracts : ed. A XIV-a, Turda, 2012. Cluj-Napoca : Casa Cartii de Stiinta, 2012, $74 \mathrm{p}$ (p.13-14)

2. Iu. Simionca, M.Hoteteu, O.Mera, N.Grudnicki, C.Munteanu, H. Lazarescu, L.Enache, D.Cinteza, R.Calin., D.Ciotaru, G.Stoian, G.Maiorescu CONFERINTA NATIONALA DE SPELEOTERAPIE CU PARTICIPARE INTERNATIONALA - REZUMATELE COMUNICARILOR STIINTIFICE. Studiu complex medico-biologic in vederea utilizarii innovative a factorilor terapeutici de mediu din saline si pestera in sanatate si turism balneoclimatic, solutii de modelare a acestora : conferinta nationala : Turda, octombrie 2011 / coord.: cercetator stiintific principal II, Dr. Iuri Simionca.Cluj-Napoca : Casa Cartii de Stiinta, 2012, 73 p. ISBN 978-606-17-0091-2 
3. Simiyonka (Simionca) J.M., Chonka J.V. (1998). To the study of using speleotherapy in the salt mines of the countries of Central Europe. International Symposium of Speleotherapy. UIS UNESCO, Permanente Commission de Speleoterapie (September 17-20, 1998). Abstracts. Solotvino, Ukraine, 1998, p.23.

4. Simionca Iu. (Ghe.), Hoteteu M., Grudnicki N., Kiss J., Enache L., Petec Calin Ghe., Rogojan Rodica, Matei Mihaela. (2005).: Environment study in order use potential therapeutic factors existing in the cavity of one salt mine for the achievement of some perspectives of speleotherapy development in Romania. 14th International Congress of Speleology. Athens-Kalamos, 21-28 August 2005. Proceedings of the 14 th International Congress of Speleology. International Union of Speleology (UIS). Hellenic Speleological Society, Vol.2, p. $421-426$.

5. Simionca Iuri (Gheorghe) Mihail, Enache Liviu Mircea Gh., Hoteteu Mihail Stefan, Buturugă Alexandru, Kiss Iaroslav, Ursaciuc Cornel, Cinteză Delia, Rogojan Rodica, Munteanu Ana, Petec Calin Gheorghe, Georgescu Ileana. (2006).: Perspective for Speleotherapy Subterranean Climatotherapy in Romanian Saline Mines and Caves. $35^{\text {th }}$ Congress of the International Society of Medical Hydrology \& Climatology. Abstracts. Istanbul, Iune 6-10, 2006, p.136.

6. Simionca Iu. (Ghe.), Cinceza Delia, Kiss Ia. (2006). Consideraţii privind statusul şi perspectivele cercetării ştiinţifice în domeniul utilizării medicale a unor factori terapeutici naturali (de mediu) în România în contextul modern de dezvoltare a cercetării europene. Al 29-lea Congres Naţional de Medicină Fizică şi de Recuperare. Volum de lucrări. România, Poiana Braşov, 1-4 noiembrie 2006, p.150158.

7. Simionca I., Grudnicki N., Buturuga A., Hoteteu M., Kiss J., Oprina A. Speleoterapia bolnavilor cu astm bronsic non-sever prin intermediul factorilor terapeutici din Salina SlanicPrahova, Corectia statusului imun. Editura "George Tofan", Suceava, 2009, 42 p., ISBN 978-973-1862-87-3

8. Spannagel K. Die medicinische Wirkung der Kluterthöhle au des asthma breonchiale und die chronische bronchitis./ Jahresheft für Karst. - U.Hö hlebunde, München, 1961, p.28

9. Sculimowski M. Treatment of bronchial asthma patients in the chamber of the rock salt mine in Wieliczka (1965) Arch. Phys.Therapie. (Leipz), 1965 Nov-Dec; 17 (6):417-21

10. Trimmel H. Die bisherigen veröffentlichungen der commission für speläotherapie der internationalen union für speläologie. In: BEITRÄGE ZU SPELÄOTHERAPIE UND HÖHLENKLIMA, II. Akten des 10. Internationalen symposiums für speläotherapie, Bad Bleiberg (Kärnten), october 1992 / Proceedings of the 10th International symposium of speleotherapy, Bad Bleiberg (Carinthia), October 1992 (Gesamtredaktion: Drahoslav Řičnýy, Beate Sandri und Hubert Trimmel). Verband österreichischer Höhlenforscher, Österreich, Wien, 1994, 306 p. (P. 28-32) 